УДК 536.24:621.184.5

DOI https://doi.org/10.32838/2663-5941/2019.6-1/40

\title{
Шелешей Т.В.
}

Національний технічний університет України

«Київський політехнічний інститут імені Ігоря Сікорського»

\section{ЗВ'ЯЗОК ТЕМПЕРАТУРИ ВІДХІДНИХ ГАЗІВ І ШКІДЛИВИХ ВИКИДІВ В АТМОСФЕРУ ПІД ЧАС СПАЛЮВАННЯ РІЗНИХ ВИДІВ ПАЛИВА}

Україною, як членом Енергетичного Співтовариства з 1 лютого 2011 року, прийнято зобов'язання дотримуватися положень Договору про заснування Енергетичного Співтовариства та додатків до нього. Краӥнам СС дозволяється застосування перехідного національного плану з пролонгачією строку досягнення деякими спалювальними установками вимог Директиви 2010/75/СС до 30 червня 2020 року. Тому є доцільним розвиток технологій, що сприятимуть покращенню ситуачї $і$ подальщому розвиткові в екологічного напряму. До таких належать, зокрема, технології, щэо сприяють зниженню температури відхідних газів.

Зниження температури відхідних газів і корисне використання їх тепла у циклі ТЕС дозволяє підвищити ККД котла і всієї станиії загалом. Втрати $q_{2}$, \% визначаються насамперед температурою від-

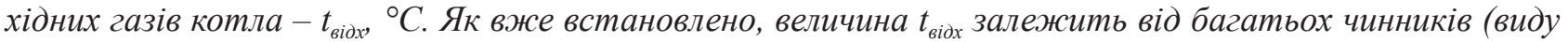
палива, компонування поверхонь нагріву котла, ступеня їх забруднення тощо), та її вибір є технікоекономічним завданням. Переваги з екологічної точки зору є такими: зниження температури відхідних газів призводить до зниження викидів оксидів азоту на 250 г/ГДж $і$ зниження оксидів вуглеию на 52 г/ГДж. Щодо котла ТГМ-96А, то зниження температури відхідних газів до безпечної для надійності газовідвідних трактів котла призводить до зниження викидів оксидів азоту і вуглеию і становить 40г/ГДж і 10г/ГДж відповідно. Аналіз отриманих результатів показав, ще емісії оксидів азоту й оксидів вуглечю зростають на 22г/ГДж і 11г/ГДж, відповідно, під час зростання температури відхідних газів на $1^{\circ} \mathrm{C}$ під час спалювання кам'яного вугілля.

Емісії оксидів азоту і вуглеињю зростають як для T-250-240 і T-100-130 під час зростання температури відхідних газів на $1{ }^{\circ} \mathrm{C}$. Таке зростання складає 10г/ГДж (оксиди азоту для T-100-130); 172/ГДж (оксиди азоту для T-250-240);2,4 г/ГДю (оксиди вуглещю для T-100-130) i 3,8 г/ГДж (оксиди вуглещю для T-250-240).

Ключові слова: котел, змінний режим експлуатаџї, температура відхідних газів, електрична потужність, теплове навантаження, температура та витрата живильної води.

Постановка проблеми. Україною, як членом Енергетичного Співтовариства 31 лютого 2011 року, прийнято зобов'язання дотримуватися положень Договору про заснування Енергетичного Співтовариства та додатків до нього. Згідно 3 Додатком II до Договору всі великі спалювальні установки після 31 грудня 2017 року мають відповідати вимогам Директиви 2001/80/СС про обмеження викидів деяких забруднюючих речовин у повітря від великих спалювальних установок (далі - Директива 2001/80/СС).

Термін часу, що залишився до введення в дію вимог Директиви 2001/80/ЄC, поточний стан обладнання наявних великих спалювальних установок в Україні, кількість яких перевищує 220 , значний обсяг робіт та обмежені фінансові ресурси операторів, що обслуговують великі спалювальні установки, не дозволяють Україні вчасно виконати вимоги Директиви 2001/80/ЄС. Через недотримання вимог українського екологічного законодавства більшість великих спалюваль- них установок має бути виведена 3 експлуатації, що призведе до зменшення наявних потужностей у національній енергетичній системі та зниження виробітку електричної і теплової енергії. Можливість для України тимчасового відступу від вимог Директиви 2001/80/СС шляхом впровадження Національного плану скорочення викидів має суттєве значення для енергетичної безпеки держави.

Директивою 2010/75/ЄC про промислові викиди (далі - Директива 2010/75/СС), що прийнята на зміну Директиви 2001/80/СС, внесено принципові зміни до чинного законодавства СС. Одна з найбільш важливих змін полягає у більш жорстких допустимих граничних значеннях викидів діоксиду сірки, оксидів азоту та пилу від великих спалювальних установок. Ці вимоги набувають чинності в країнах ЄС для великих спалювальних установок 31 січня 2016 року. При цьому країнам ЄС дозволяється застосування перехідного національного плану 3 пролонгацією строку досягнення деякими спалювальними 
установками вимог Директиви 2010/75/СС до 30 червня 2020 року. Згідно 3 рішенням Ради Міністрів Енергетичного Співтовариства від 24 жовтня 2013 року вимоги Директиви 2010/75/ЄС набувають чинності в Енергетичному Співтоваристві для великих спалювальних установок після 31 грудня 2027 року. [1] Тому, в зв’язку з вищесказаним, є доцільним розвиток технологій, що сприятимуть покращенню ситуації і подальшому розвиткові екологічного напряму. До таких і належать технології, що сприяють пониженню температури відхідних газів.

Аналіз останніх досліджень і публікацій. Першою спробою визначення доцільного рівня підігріву повітря в котельному агрегаті слід вважати роботу B.I. Толубінского [2], що є продовженням досліджень Л.К. Рамзіна [3] і Р.В. Петеліна [4]. В.I. Толубінский запропонував спрощену аналітичну методику, що дозволяє розраховувати оптимальні температури димових газів за найвигіднішого розподілу теплосприйняття між економайзером і повітропідігрівачем у разі одноступеневого компонування.

На початку 50-х років великі дослідження в цьому напряму були проведені Н.В. Кузнєцовим, І.Б. Варавицьким і Л.Б. Кролем [4; 5], які показали, що температура вихідних газів пов'язана 3 температурами повітря на вході в повітронагрівач і живильної води, зі значеннями повних теплоємностей - водяних еквівалентів повітря і продуктів згоряння, з величинами мінімальних температурних напорів між гріючим і нагріваючим середовищами.

Надалі робота по відшуканню найбільш раціональної компоновки хвостових поверхонь нагріву котельних агрегатів поділяється на два великих напрями: 1) найвигідніший розподіл теплосприймання між ступенями нагріву економайзера і повітропідігрівника, включаючи спільне визначення оптимальних температур живильної води і відхідних газів; 2) відшукання найбільш раціональної схеми попереднього та основного підігріву повітря як засобу боротьби з низькотемпературною корозією, підвищення економічності спалювання палива і економічності блоку в цілому, враховуючи при цьому вплив температури гарячого повітря на утворення шкідливих речовин в топках котлів.

Дослідження в цьому напряму, слідом за ВTI, проводилися в MEI Т.Х. Маргуловой [5], ЦКТІ С.П. Невельсоном [6], М.А. Стириковичем, P.А. Матвєєвим і В.I. Белясвим [7]. Причому в зазначених роботах ЦКТІ особлива увага приді- лялася залежності оптимальної температури відхідних газів від розрахункової вартості палива.

Одним з основних факторів, що впливають на оптимальну температуру димових газів, $є$ температура живильної води. 3 іншого боку, як показали дослідження А.В. Андрющенко [8; 9], вибір оптимальної температури живильної води повинен проводитися з урахуванням залежності втрат теплоти 3 димовими газами. В іншому випадку температура живильної води виходить завищеною.

Великі дослідження по спільному визначенню оптимальних температур живильної води і відхідних газів для різних умов експлуатації були проведені в ЦКТІ А.П. Ніконовим [10], А.Е.Гельтманом, К.Е. Алатовським, С.Й.Мочаномі I.Н. Комісарчиком [10-11] в MEI М.А. Дєвочкіним [5]. Крім того, дослідженнями Іванівського енергетичного інституту [9] було додатково показано вплив пилеприготування на величину оптимальної температури відхідних газів.

Робота котельного агрегату на режимах, що відрізняються від проектного, вельми характерна для реальних експлуатаційних умов. Одним 3 основних факторів, що викликають нерозрахунковий режим роботи котла, $є$ зміна температури живильної води. В експлуатації можливе часткове відключення регенеративних підігрівачів, зниження підігріву в них може відбуватися також внаслідок забруднення поверхні нагріву. При блочних установках температура живильної води тісно пов'язана 3 навантаженням блоку.

Наведений вище огляд досліджень по відшуканню найвигіднішого розподілу теплосприймання між ступенями нагріву економайзера і повітропідігрівника, включаючи спільне визначення оптимальних температур живильної води і відхідних газів показує, що названим питанням приділяється досить велика увага, і їх слід вважати достатньо обгрунтованими.

Постановка завдання. Великі енергетичні установки мають низку шкідливих викидів, а саме оксиди азоту, оксиди сірки, оксиди вуглецю, тверді частинки і важкі метали. Тому основним завданням нашої статті $є$ встановлення взаємозв'язку температури відхідних газів і викидів оксидів азоту, сірки вуглецю для станцій блочного типу i 3 поперечними зв'язками при спалюванні різних видів палива.

Виклад основного матеріалу дослідження. Втрати $\mathrm{q}_{2}, \%$ визначаються, насамперед, температурою відхідних газів котла $-t_{\text {відх}},{ }^{\circ} \mathrm{C}$. Розглянемо вплив $\mathrm{t}_{\text {відх }}$ на екологічні показники для блоків 
T-250-240, Т-100-130 при спалюванні природного газу і для К-300-240 при спалюванні кам'яного вугілля.

На рис 1 показано залежність емісії оксидів сірки від температури відхідних газів для блоків К-300-240 при спалюванні кам'яного вугілля.

3 графіка видно, що з ростом температури відхідних газів на $1{ }^{\circ} \mathrm{C}$ емісія оксидів сірки при спалюванні кам'яного вугілля зростають на 72 г/ГДж. Щодо викидів оксидів азоту, то залежність емісій оксидів азоту і оксидів вуглецю від температури відхідних газів при спалюванні кам'яного вугілля показана на рис. 2-3.

Аналіз отриманих результатів показав, що емісії оксидів азоту і оксидів вуглецю зростають на 22г/ГДж і 11г/ГДж відповідно при зростанні температури відхідних газів на $1{ }^{\circ} \mathrm{C}$ при спалюванні кам'яного вугілля.

Розглянемо емісії викидів оксидів азоту і вуглецю для блоків Т-250-240 і Т-100-130 при спалюванні природного газу. Такі залежності показані на рис. $4-5$.

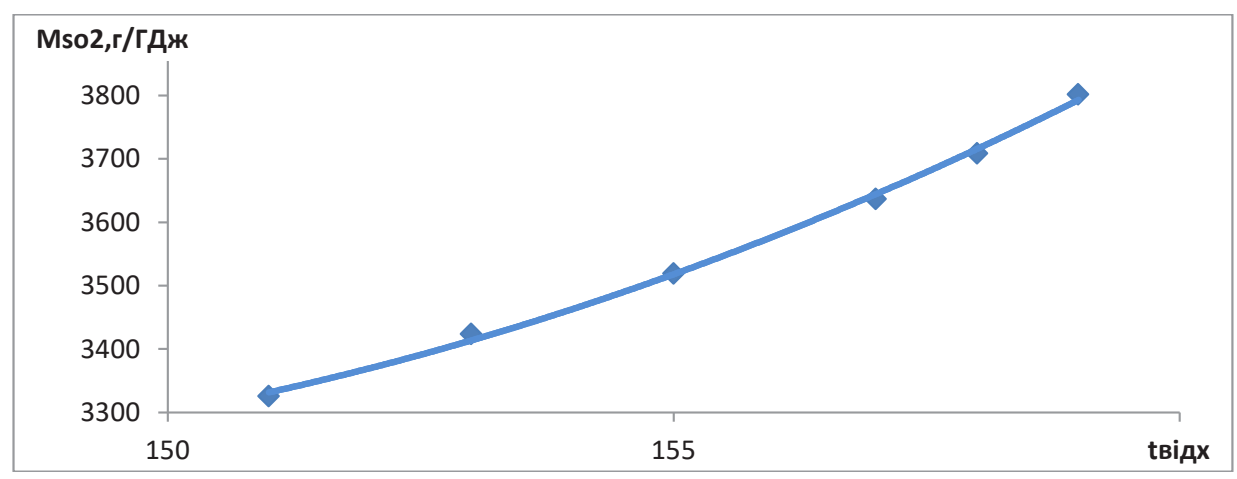

Рис. 1. Залежність емісії оксидів сірки від температури відхідних газів для блоків К-300-240 при спалюванні кам'яного вугілля

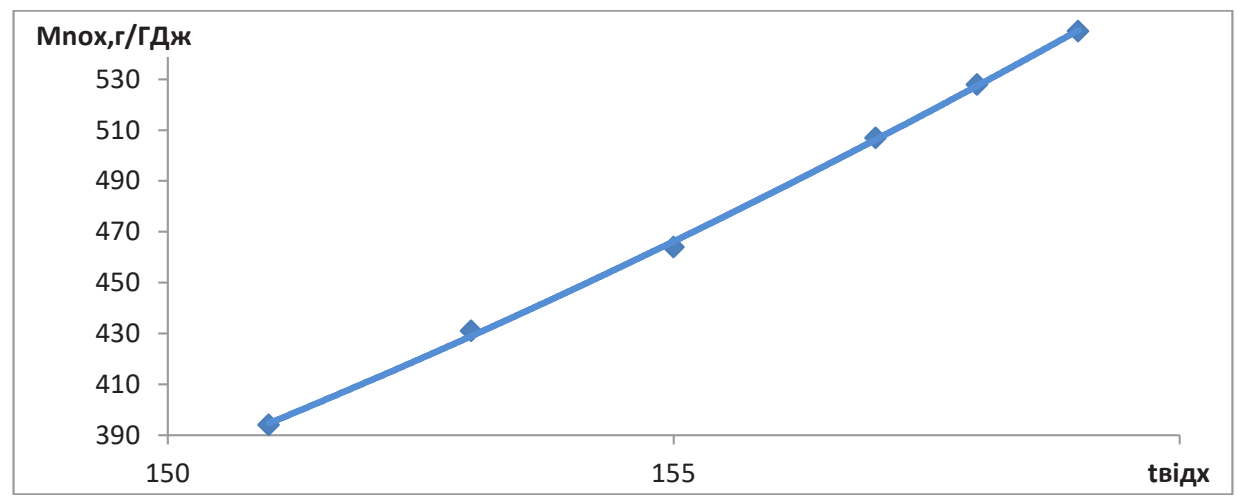

Рис. 2. Залежність емісії оксидів азоту від температури відхідних газів для блоків К-300-240 при спалюванні кам'яного вугілля

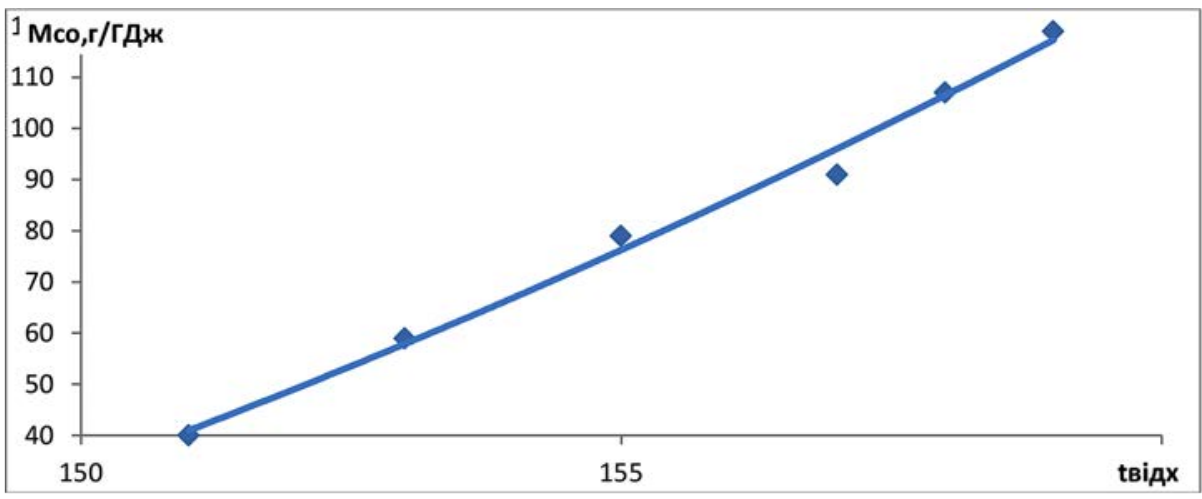

Рис. 3. Залежність емісії оксидів вуглецю від температури відхідних газів для блоків К-300-240 при спалюванні кам'яного вугілля 


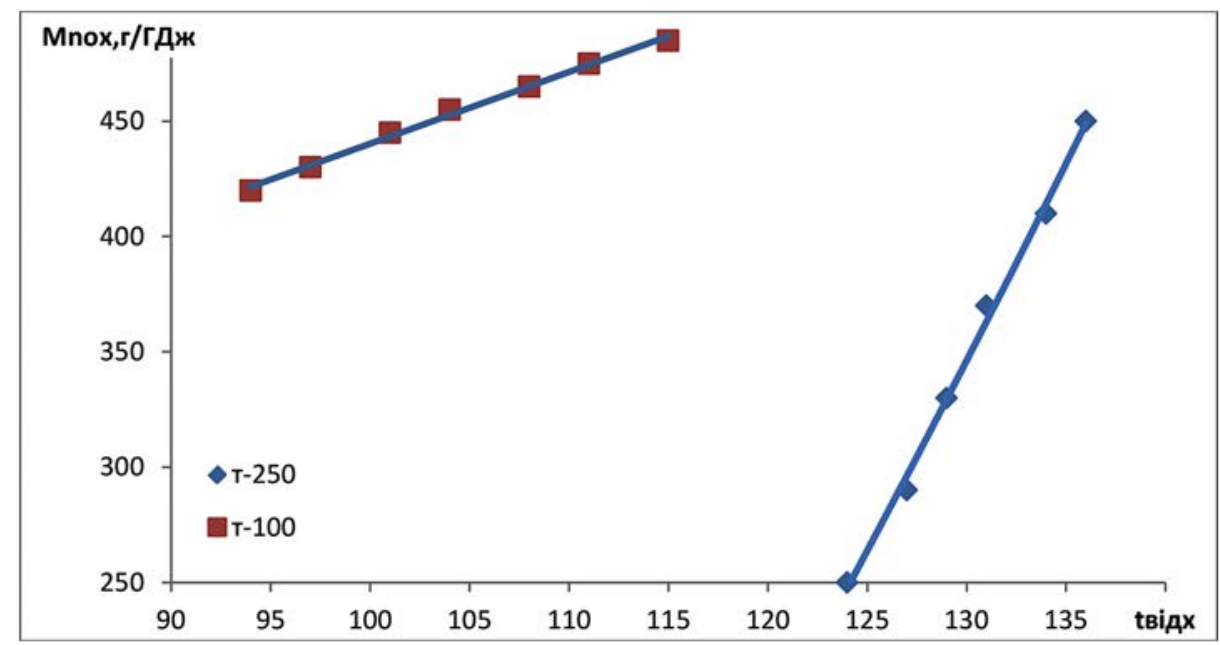

Рис. 4. Залежність емісій оксидів азоту від температури відхідних газів для блоків Т-250-240(1), Т-100-130(2) при спалюванні природного газу

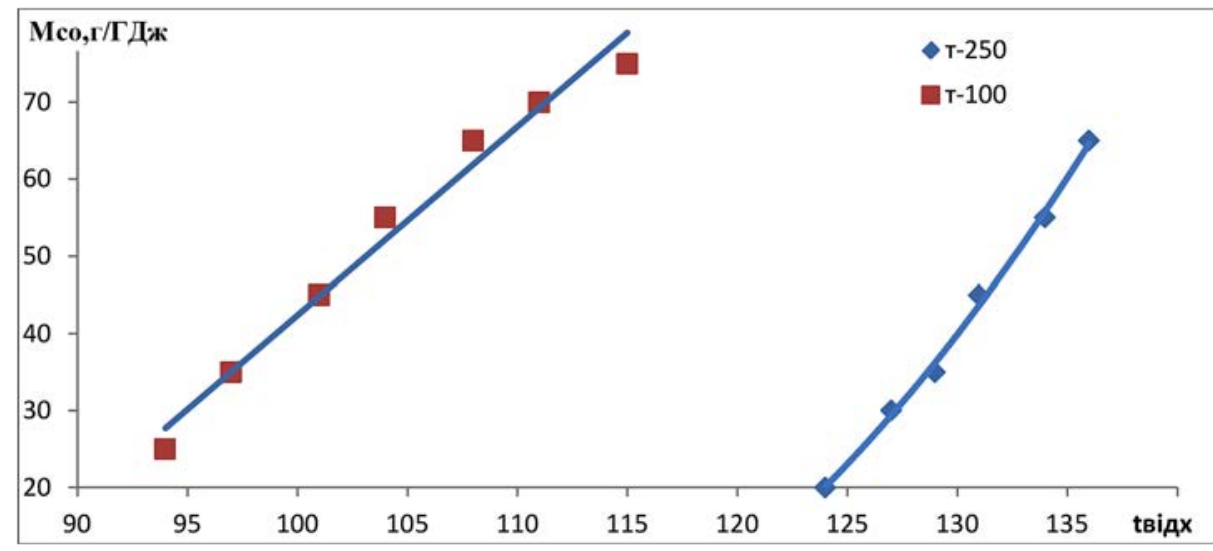

Рис. 5. Залежність емісій оксидів вуглецю від температури відхідних газів для блоків Т-250-240(1), Т-100-130(2) при спалюванні природного газу

3 рисунків видно, що емісії оксидів азоту і вуглецю зростають як для Т-250-240 і Т-100130 за зростання температури відхідних газів на $1{ }^{\circ} \mathrm{C}$. Таке зростання складає $10 г /$ ДДж (оксиди азоту для Т-100-130); 17г/ГДж (оксиди азоту для Т-250-240);2,4 г/ГДж (оксиди вуглецю для Т-100-130) i 3,8 г/ГДж (оксиди вуглецю для Т-250-240).

Переваги $з$ екологічної точки зору є такими: зниження температури відхідних газів призводить до зниження викидів оксидів азоту на 250 г/ГДж і зниження оксидів вуглецю на 52 г/ГДж. Щодо котла ТГМ-96А, то зниження температури відхідних газів до безпечної для надійності газовідвідних трактів котла, то це призведе до зниження викидів оксидів азоту і вуглецю становить 40г/ГДж і 10г/ГДж відповідно.

Зменшення емісій оксидів сірки, азоту і вуглецю для котла ТПП-210 А при спалюванні кам'яного вугілля складають 720г/ГДж, 220г/ГДж і 110 г/ГДж відповідно.

\section{Висновки.}

1. Україною, як членом Енергетичного Співтовариства 31 лютого 2011 року, прийнято зобов'язання дотримуватися положень Договору про заснування Енергетичного Співтовариства. $€$ доцільним розвиток технологій, що сприятимуть покращенню ситуації і подальшому розвиткові в екологічного напряму. До таких і належать технології, що сприяють пониженню температури відхідних газів.

2. 3 ростом температури відхідних газів на $1^{\circ} \mathrm{C}$ емісія оксидів сірки при спалюванні кам'яного вугілля зростають на 72 г/ГДж.

3. Аналіз отриманих результатів показав, що емісії оксидів азоту і оксидів вуглецю зростають на 22г/ГДж і 11г/ГДж відповідно при зростанні температури відхідних газів на $1 \mathrm{C}^{\circ}$ при спалюванні кам'яного вугілля.

4. Емісії оксидів азоту і вуглецю зростають як для Т-250-240 і Т-100-130 при зростанні тем- 
ператури відхідних газів на $1^{\circ} \mathrm{C}$. Таке зростання складає 10г/ГДж (оксиди азоту для Т-100-130); 17г/ГДж (оксиди азоту для Т-250-240); 2,4 г/ГДж (оксиди вуглецю для Т-100-130) i 3,8 г/ГДж (оксиди вуглецю для Т-250-240).

5. Переваги з екологічної точки зору є такими: зниження температури відхідних газів призводить до зниження викидів оксидів азоту на 250 г/ГДж і зниження оксидів вуглецю на 52 г/ГДж.
Щодо котла ТГМ-96А то зниження температури відхідних газів до безпечної для надійності газовідвідних трактів котла, то це призведе до зниження викидів оксидів азоту і вуглецю становить 40г/ГДж і 10г/ГДж відповідно.

6. Зменшення емісій оксидів сірки, азоту i вуглецю для котла ТПП-210 А при спалюванні кам'яного вугілля складають 720г/ГДж, 220г/ГДж і 110 г/ГДж відповідно.

\section{Список літератури:}

1. Національний план скорочення викидів від великих енергетичних установок. від 8 листопада 2017 року № 796-р. Київ. Розпорядження, Кабінет міністрів України. С. 99.

2. Інноваційні пріоритети паливно-енергетичного комплексу України / заг. ред. А.К. Шидловський. Київ : Українські енциклопедичні знання, 2005. 512 с.

3. He J., Zhang W. Techno-economic evaluation of thermo-chemical biomaffi-io-ethanol. Appl. Energy. 2011. № 4 (88). P. 1224-1232.

4. Вольчин I.А., Дунаєвська Н.І., Гапонич Л.С., Чернявський М.В., Токал О.І., Засядько Я.І. Перспективи впровадження чистих вугільних технологій в енергетику України, Київ, ГНОЗІС. 2013. С. 28

5. Андерсон Э., Бродов Ю.М., Плотников П.Н. и др. Анализ показателей надежности вспомогательного оборудования энергоблоков. Теплоэнергетика. 2011. №8. С. 2-7.

6. Овчар В.Г., Гордеев В.В., Сотников И.А., Липец А.У. Опыт заводских разработок энергоблоков повышенной эффективности. Теплоэнергетика. 1999. №9. С. 2-5

7. Коваленко П.Ю. Оптимизация энергоблоков повышенной эффективности на основе турбин Т-100-130. Энергосистемы, электростанции и их агрегаты: Сборник научных трудов НГТУ. Вып. 8. Новосибирск : Изд-во НГТУ. 2004. С. 62-79.

8. Шинников П.А., Ноздренко Г.В., Ловцов А.А. Эффективность реконструкции пылеугольных паротурбинных ТЭЦ в парогазовые путем газотурбинной надстройки и исследование показателей их функционирования. Новосибирск : Наука, 2002. 97 с.

9. Шинников П.А., Серант Ф.А., Коваленко П.Ю. и др. Повышение эффективности энергоблоков ТЭЦ. Ползуновский вестник №1. Барнаул : Изд-во АлтГТУ им. Ползунова, 2004. С. 210-215.

10. Шелешей Т.В. Взаємозв'язок температури відхідних газів і техніко-економічних та екологічних показників ТЕЦ. Вісник НТУ «ХПІ». Серія: Енергетичні та теплотехнічні процеси й устаткування. Харків : НТУ «ХПІ». 2018. № 11(1287). С. 32-35.

\section{Sheleshey T.V. BACKGROUND OF THE TEMPERATURE OF THE FUEL GASES AND HARMFUL EMISSIONS IN THE ATMOSPHERE WITH THE BURNING OF DIFFERENT KINDS OF FUEL}

Ukraine, as a member of the Energy Community since February 1, 2011, has undertaken to comply with the provisions of the Treaty establishing the Energy Community and its annexes. EU countries are permitted to apply a transitional national plan extending the deadline for certain combustion plants to meet the requirements of Directive 2010/75 / EC by 30 June 2020.

Therefore, in connection with the above, it is advisable to develop technologies that will improve the situation and further development in environmental issues. These include technologies that contribute to reducing the temperature of exhaust gases.

Reducing the temperature of the exhaust gases and the beneficial use of their heat in the TPP cycle allows to increase the efficiency of the boiler and the whole station as a whole. The losses $q_{2}, \%$ are determined, first of all, by the boiler exhaust gas temperature - from, ${ }^{\circ} \mathrm{C}$. As already established, the value here depends on many factors (type of fuel, arrangement of boiler heating surfaces, degree of contamination, etc.) and its choice is a technical and economic task. The environmental benefits are: lowering the exhaust gas temperature leads to a reduction in nitrogen oxide emissions of $250 \mathrm{~g} / \mathrm{GJ}$ and a reduction of carbon oxides by $52 \mathrm{~g} / \mathrm{GJ}$. With respect to the TGM-96A boiler, the reduction of the exhaust gas temperature to the safe for the reliable gas outlet tracts of the boiler will lead to the reduction of nitrogen and carbon oxide emissions by $40 \mathrm{~g} / \mathrm{GJ}$ and $10 \mathrm{~g} / \mathrm{GJ}$ respectively. The analysis of the results showed that the emissions of nitrogen oxides and carbon oxides increase by $22 \mathrm{~g} / \mathrm{GJ}$ and $11 \mathrm{~g} / \mathrm{GJ}$ respectively when the flue gas temperature rises by $1{ }^{\circ} \mathrm{C}$ when burning coal.

Emissions of nitrogen and carbon oxides increase for both T-250-240 and T-100-130 as the exhaust gas temperature rises by $1{ }^{\circ} \mathrm{C}$. This increase is $10 \mathrm{~g} / \mathrm{GJ}$ (nitrogen oxides for T-100-130); $17 \mathrm{~g} / \mathrm{GJ}$ (nitrogen oxides for T-250-240); $2.4 \mathrm{~g} / \mathrm{GJ}$ (carbon oxides for T-100-130) and $3.8 \mathrm{~g} / \mathrm{GJ}$ (carbon oxides for T-250-240).

Key words: boiler, variable operating mode, temperature of exhaust gases, electric power, thermal load, temperature and consumption of feed water. 